\author{
A.T. Ибрагимова ${ }^{l}$ Wu Chuke $^{2}$ \\ ${ }^{1}$ докторант, Евразийский Национальный Университет имени Л.Н. Гумилева, \\ 2. Нур-Султан, Казахстан \\ ${ }^{2}$ Профессор Школь Соџиологии и Этнологии Университета Ming Zu, \\ г. Пекин, КНР
}

\title{
ТЕРРИТОРИАЛЬНЫЕ СПОРЫ КИТАЯ В ЮЖНО-КИТАЙСКОМ МОРЕ
}

\begin{abstract}
Аннотаиия
Пекин на протяжении десятилетий ведет споры с несколькими странамиАзиатскоТихоокеанскогорегиона по поводу территориальнойпринадлежностиряда островов в ЮжноКитайском море, на шельфе которых были обнаруженызначительныезапасы углеводородов. Речь идет прежде всего об архипелагеСиша (Парасельскиеострова), островахНаньша (Спратли) и Хуанъянь (риф Скарборо). В этот спор в той или иной степени вовлечены Вьетнам, Бруней, Малайзия и Филиппины.

США не являются стороной спора, но не признают претензии Китая и настаиваютна своем праве «свободного судоходства» в регионе.

Ключевые слова: конфликт, Южно-китайское море, Китай, США, КНР, АТР.

$$
\begin{gathered}
\text { А.Т. Ибрагимова }{ }^{1} \text { Wи Chике } \\
{ }^{2} \text { Гумилев атындагы Еуразия ұлттық университетіның докторанті } \\
\text { Нур-Султан қ., Қазақстан } \\
{ }^{2} \text { Социология және этнология мектебінің профессоры, Мин Зу университеті, } \\
\text { Бейжің қаласы, Қытай }
\end{gathered}
$$
\end{abstract}

\section{ТЕРРИТОРИАЛЬНЫЕ СПОРЫ КИТАЯ В ЮЖНО-КИТАЙСКОМ МОРЕ}

\section{Aң̧датnа}

Бейжің ондаған жылдар бойы Азия-Тынық мұхиты аймағының бірнеше елімен Оңтүстік Қытай теңізіндегі бірқатар аралдарға аумақтық иелік ету туралы дау-дамайға түсіп келді, олардың қасында көмірсутектердің айтарлықтай қорлары табылды. Біз ең алдымен Сиша архипелагы (Парасель аралдары), Нанша (Спратли) және Хуангянь (Скарборо рифі) аралдары туралы айтамыз. Бұл пікірталасқа Вьетнам, Бруней, Малайзия және Филиппин қатысады. Америка Құрама Штаттары даудың тарабы емес, бірақ ол Қытайдың талаптарын мойындамайды және оның аймақтағы «тегін тасымалдау» құқығын талап етеді.

Түйінді сөздер: қақтығыс, Оңтүстік Қытай теңізі, Қытай, АҚШ, Қытай, Азия-Тынық мұхиты.

\author{
Ibragimova A.T. ${ }^{1}$ Wu Chuke $e^{2}$ \\ ${ }^{1}$ PhD student, Eurasian National University named after L.N. Gumilyova, \\ Nur-Sultan, Kazakhstan \\ ${ }^{2}$ Professor, School of Sociology and Ethnology, Ming Zu University, \\ Beijing, China
}

\section{ТЕРРИТОРИАЛЬНЫЕ СПОРЫ КИТАЯ В ЮЖНО-КИТАЙСКОМ МОРЕ}

\section{Abstract}

For decades, Beijing has been arguing with several countries of the Asia-Pacific region over the territorial ownership of a number of islands in the South China Sea, on the shelf of which significant hydrocarbon reserves were discovered. We are talking primarily about the Sisha archipelago (Paraselsky 
Islands), the Nansha (Spratly) and Huangyan (Scarborough Reef) islands. Vietnam, Brunei, Malaysia and the Philippines are involved in this debate to one degree or another. The United States is not a party to the dispute, but it does not recognize the claims of China and insists on its right to "free shipping" in the region.

Key words: conflict, South China Sea, China, USA, China, Asia-Pacific.

Сегодня Южно-Китайское море - один из самых взрывоопасных регионов планеты.

Территориальные споры в Южно-китайском море возникливследствие того, что Японская империяпо Сан-Францисскому мирному договору 1951 года отреклась от этих территорий, и данные острова и архипелаги в регионе заняли КНР, Тайвань, Вьетнам, Филиппины, Малайзия и Бруней [1].Таким образом, расположенный на севере Южно-Китайскойакватории архипелагСиша (Парасельскиеострова)достался КНР, а находящиеся южнее островаНаньша (Спратли) и Хуанъянь (риф Скарборо) контролировали целый ряд государств, выдвигающие взаимные территориальные претензии [2]. Вьетнам утверждает о том, что он результативноприменял свою юрисдикцию по отношениюи Парасельских островов, и островов Спратли с XVII века и имеет необходимые для обоснования собственных претензий документы. Филиппин обосновывают свои претензии в Южно-Китайской акватории географической близостью к островам Спратли [3]. Также Малайзия и Бруней согласно конвенции ООН «О морском праве» от 1982 годав том числепытаютсяобосновать свои исключительные экономические зоны в Южно-китайском море. У Малайзиитакже существуют претензии на часть острововНаньша (Спратли). Но наибольшими территориальными претензиями в регионе обладает Китай: КНР претендует на территорию по «линии из девяти пунктиров», т.е.около $80 \%$ акватории Южно-китайского морясогласно историческим картам, а также атласуКНР 1947 года, полностью включающий в территорию Китайской республики как Парасельские острова, так и острова Наньша (Спратли). Отсюда, претензии Китайской республикиопределяются «историческим» правом Китая, «испокон веков» владеющийэтими территориями. Данные претензиитаким же образом выдвигает и Тайвань (официальное название - Китайская республика) [2]. Отсюда, Китаем, Тайванем и Вьетнамом выдвигаются претензии на данные территориивследствие исторических прав, тогда как требования Малайзии, Филиппин и Брунеяосновываютсясогласно положений конвенции ООН.

Для Китая этот район стратегически важен, потому что, господствуя в центральной части Южно-Китайского моря, можно угрожать Филиппинам, Индонезии, Малайзии и, конечно, Ханою, который является главным геополитическим противником Пекина в регионе.

Еще с середины XX века Китай претендует на всю центральную часть акватории ЮжноКитайского моря. Парасельские острова и острова Спратли на самом деле всего лишь коралловые рифы, атоллы и даже заливаемые водой банки, глубиной до полутора метров. Но поскольку со второй половины XX века территориальные претензии выдвигаются даже за самые незначительные клочки земли, в Южно-Китайском море имеет место именно такая ситуация. Тот, кто будет контролирует эти рифы, будет контролировать и Южно-Китайское море, которое является очень удобным узлом морских перевозок [4].

В 2012 годупротивостояние имелоопределеннуюэскалацию и опять привлекло к себе внимание: Китайская республика установила контроль над островом Хуанъянь (риф Скарборо), на который Филиппины выдвигают претензии. В связи с этим, в начале 2013 года Филиппины при большой политической и дипломатической поддержке США подали на КНР жалобу в Гаагу, в Постоянную палату третейского суда. Но уже через месяц после этого шага Китайская республика заявила о непризнании ею будущего решения данного третейского суда. 12 июля 2016 года после длительного процесса рассмотрения, панелью международных экспертов, которая действовала под эгидой Постоянной палаты третейского суда в Гааге, было вынесено решение по делу № 2013-19 «Республика Филиппины против Китая». Третейский суд постановил, что территория, на которую претендует Китай, не являются островами, а рифами и скалами, вследствие чего никакой «исключительной зоны» вокруг этих объектов нельзя установить. Также не посчитали аргументами доводы Китайской республикив отношении «линии из девяти пунктиров».

Китайское руководствоотреагировало отрицательно. Согласно заявлениюДай Бинго, одного из советников Си Цзиньпина по внешней политике, «это решение лишь «клочок бумаги» [5]. Таким образом, руководство Китая заняло позицию четырех «нет»: «не соглашаться», «не участвовать», «не признавать», «не исполнять». 
Одна из важных причин противостояния в последние годы - увеличивающаяся внешнеполитическая активность КНР, что, очень важно, по объективным данным связано с постояннымростом его экономическиго и военногопотенциала.

Хотя Парасельские острова и архипелаг Спратлималонаселены, эти участки суши и акватория Южно-Китайского моря вокруг, очень ценны вследствие содержания богатых полезных ископаемых. Согласно наиболее достовернойинформации, приведенной Энергетическим управлением США, там содержится около 11 млрд. баррелей нефти и 538 млрд. кубометров газа [1].

Также значительное напряжение вызывается отловом морской рыбы. На акваторию ЮжноКитайского моря приходится примерно 12\% мировой добычи этого продукта [6]. Китаем рассматриваетсяданная отрасль как стратегически важная: например, в 2015 году она составила около 3\% ВВП государства, в отрасли рыболовстваработают примерно 9 млн. рабочих, при том длябольшинства это является единственным вариантом трудоустройства. Значимость ЮжноКитайского моряувеличивается и вследствиесвысоким уровнем загрязненности прибрежных и внутренних вод Китая промышленными отходами.

Но все же ресурсный потенциал Южно-Китайского моря не является главным источникомтерриториальных споров. В данной акватории существует Малаккский пролив, через который ежегодный проходит 5,3 трлн. долларов (примерно 25\% всей мировой торговли) торгового траффика[1]. Благодаря этому проливупроисходит около $60 \%$ внешнеторговых операций Китая, в который входит и $80 \%$ импорта углеводородов. При этом Малаккский пролив очень узкий (наименьшая ширина - 2,5 км). Политическое и военное руководство Китая очень беспокоится, что вследствие какого-тоспора пролив легко будет перекрыт флотом США. ОбеспокоенностьКНР подкрепляется активным обсуждением этого сценария, его плюсов и минусов, в американской экспертной среде и в кругах военно-политической элиты. Отсюда, контроль над территорией Южно-Китайского морянужен Китаю для того, чтобы конкурирующие страны и США в качестве их союзников не перекрылистратегически важные в экономической сфере для КНР пути и, вследствие чего, осуществить экономическую блокаду.

Китай как вторая по величине экономика мира представляет для Соединенных Штатов определенную опасность. Китай очень активно проникает в страны Африки, Латинской Америки. Со стороны США фактором сдерживания является выстраивание вокруг Китая пояса враждебно настроенных государств. Главная роль в этом процессе принадлежит двум странам - Японии, старому союзнику США, и Вьетнаму - новому союзнику Соединенных Штатов.

США умело пользуются территориальным спором и историческими противоречиями между главными соперниками, чтобы сдерживать Пекин. На современном этапе Южно-Китайское море занимает одно из центральных мест в ведомых США и Китаем глобальных геополитических проектах - формировании Индо-Тихоокеанского региона (ИТР) и реализации Инициативы пояса и пути (ИПП).

Сам факт возникновения проекта ИТР свидетельствует, что традиционный АзиатскоТихоокеанский регион, основанный на сотрудничестве США и КНР, фактически перестал существовать. То, что акватория Южно-Китайского моря географически находится в эпицентре будущего ИТР, способно еще более значительно «раскачать» китайско-американские противоречия по всему спектру проблем, связанных с этой акваторией.

Говоря о противостоящей США китайской «Инициативе пояса и пути», важно подчеркнуть, что к акватории Южно-Китайского моря будут выходить экономический коридор КитайИндокитай и участок Морского шелкового пути. Стремясь защитить свои инвестиции в эти глобальные проекты, Китай неизбежно будет формировать выгодную себе международную обстановку. Вероятным сценарием выглядит создание китаецентричной системы «общей безопасности». Первые признаки ее формирования - например, предложение Китая странам АСЕАН провести военно-морские маневры в Южно-Китайском море с их фиксацией в соответствии с принятыми международными практиками - уже есть.

Перспектива конкуренции американского и китайского проектов чревата большими потрясениями и формирует запрос стран региона на повышение эффективности международных механизмов, способных амортизировать современные и перспективные противоречия Вашингтона и Пекина.

Таким образом, территориальныеспоры в Южно-китайскойакватории - это конфликт, спровоцированный, главным образом, интересами сторон в экономической и геополитической области. Это противостояниеоказывается очень важнымв связи с постоянно возрастающими 
экономическими, политическими и, в первую очередь, военными возможностями Китая государства, по несколько внешне- и внутриполитическим причинам претендующей на контроль над территорией Южно-китайского моря. Носледствие того, что регион очень важен для международной экономики взаимозависимость странЮжно-китайской акватории и США, а также традиционный курс Китайской республики на мирное урегулирование конфликтов, вооруженное противостояние в регионе маловероятно. В настоящее время драйвером нестабильности в Южнокитайской акваториибудет непредсказуемость внешней политики президента США Д. Трампа, которая направлена на сдерживание КНРс помощью постепенногоухудшения положения как в Южно-китайскойакватории, так и в других важных для Китая вопросах.

Список использованной литературы:

1. Габуев А.Т. После судного дня: как будет развиваться конфликт в Южно-Китайском море: Московский центр Карнеги. 2016. URL: http://carnegie.ru/commentary/2016/07/27/ ru-64182/j39i

2. Why is the South China Sea contentious? // BBC News. 2016. 12 July. URL: http://www.bbc. com/news/world-asia-pacific-13748349

3. Bader J.A. The U.S. and China's Nine-Dash Line: Ending the Ambiguity // Brookings. 2014. February 6. URL: https://www.brookings.edu/opinions/the-u-s-and-chinas-nine-dash-lineending-theambiguity/

4. Болдырева О. Востоковед раскрыл планы США против Китая в Южно-Китайском море // https://nsn.fm/policy/vostokoved-raskryl-plany-ssha-protiv-kitaya-v-uzhno-kitaiskom-more

5. 戴秉国出席中美智库南海问题对话会开幕式并发表主旨演讲. 2016. URL： http://news. xinhuanet.com/2016-07/06/c_1119173439.htm

6. Greer A. The South China Sea Is Really a Fishery Dispute // The diplomat. 2016. July 20. URL: http://thediplomat.com/2016/07/the-south-china-sea-is-really-a-fishery-dispute/ 